\title{
NEUROCYSTICERCOSIS AND MICROSCOPIC HIPPOCAMPAL DYSPLASIA IN A PATIENT WITH REFRACTORY MESIAL TEMPORAL LOBE EPILEPSY
}

\author{
Alexandre Valotta da Silva', Heloise Helena Martins'2, Carolina Mattos Marques ${ }^{3}$, \\ Elza Marcia Targas Yacubian ${ }^{4}$, Américo Ceiki Sakamoto ${ }^{4}$, Henrique Carrete Jr. ${ }^{5}$, \\ Ricardo da Silva Centeno ${ }^{6}$, João Norberto Stavale ${ }^{7}$, Esper Abrão Cavalheiro ${ }^{8}$
}

\begin{abstract}
Epidemiologic studies suggest that neurocysticercosis (NC) is the main cause of symptomatic epilepsy in developing countries. The association between NC and mesial temporal lobe epilepsy (MTLE) has been re ported by several authors. Recent data have shown that the presence of NC does not influence the clinical and pathological profile in MTLE patients and suggest that not all cysticercotic lesions are inevitably epileptogenic. We describe a 50-years-old woman with partial seizures due to NC which evolve to MTLE. The patient was submitted to a corticoamygdalohippocampectomy to treat re f r a c t o ry epilepsy. An immunohistochemical study using neuronal markers was made on hippocampal formation. Besides the typical aspects of Ammon's horn sclerosis (AHS), the microscopic examination demonstrates cellular featu res of hippocampal malformation including dysmorphic neurons and focal bilamination of granular cell layer. We suggest that, in this case, a developmental disorder lowered the threshold for the NC-induced seizures and contributed to the establishment of refractory epilepsy.
\end{abstract}

KEY WORDS: refractory epilepsy, neurocysticercosis, dysmorphic neurons.

\section{Neurocisticercose e displasia hipocampal microscópica em paciente com epilepsia do lobo tem- poral mesial refratária.}

RESUMO - Estudos epidemiológicos sugerem que a neurocisticercose (NC) é a causa principal de epilepsia sintomática em países em desenvolvimento. A associação entre NC e epilepsia do lobo temporal mesial (ELTM) tem sido relatada por vários autores. Estudos recentes mostraram que a presença de NC não influência o perfil clínico e patológico em pacientes com ELTM e sugere que nem todas as lesões cisticercóticas são inevitavelmente epileptogênicas. No presente estudo, descrevemos uma mulher de 50 anos com crises epilépticas parciais associadas à NC que evolui para ELTM. A paciente foi submetida à corticoamigdalohipocampectomia para tratamento de epilepsia refratária. O estudo imunohistoquímico, utilizando marcadores neuronais, foi realizado em seções da formação de hipocampal. Além dos aspectos típicos da esclerose hipocampal, o exame microscópico demonstrou características celulares de malformação hipocampal, incluindo neurônios dismórficos e bilaminação focal da camada granular do giro denteado. Sugerimos que, neste caso, um transtorno do desenvolvimento reduziu o limiar para as crises epilépticas induzidas pela NC e contribuiu para o estabelecimento da epilepsia refratária.

PALAVRAS-CHAVE: epilepsia refratária, neurocisticercose, neurônios dismórficos.

It has been estimated that 50 million people are infected with the taenia/cysticercosis complex in the world and that 50,000 die each year ${ }^{1}$. Neurocysticercosis (NC) is considered a big problem in Latin Ame- rica, Africa and Ásia ${ }^{2,3}$, where many people live under deficient sanitary conditions. Agapejev 4 recently reviewed the clinical and epidemiological profile of neurocystiscercosis in Brazil, showing that epilepsy is

\footnotetext{
1'Doutor, Pesquisador do Laboratório de Neurologia Experimental da Universidade Federal de São Paulo, Escola Paulista de Medicina, São Paulo SP, Brazil (UNIFESP-EPM); ${ }^{2}$ Farmacêutica, Mestranda do Departamento de Neurologia e Neurocirurgia da UNIFESP-EPM; ${ }^{3}$ Psicóloga, Doutoranda do Departamento de Neurologia e Neurociru rgia da UNIFESP-EPM; ${ }^{4}$ Doutora, Professora do Departamento de Neurologia e Neurocirurgia da UNIFESP-EPM; ${ }^{4}$ Doutor, Professor do Departamento de Neurologia e Neurocirurgia da UNIFESPEPM; ${ }^{5}$ Médico, Doutorando do Departamento de Diagnóstico por Imagem da UNIFESP-EPM; ${ }^{6}$ Médico, Doutorando do Departamento de Neurologia e Neurociru rgia da UNIFESP-EPM; ${ }^{7}$ Doutor, Professor do Departamento de Patologia da UNIFESP-EPM; ${ }^{8}$ Doutor, P rofessor do Departamento de Neurologia e Neuro ci ru rgia da UNIFESP-EPM. This work was supported by FAPESP, CNPq and CAPES from Brazil. Dr. Alexandre Valotta da Silva received a postdoctoral grant from FAPESP (2003/01195-8).
}

Received 11 August 2005, received in final form 1 November 2005. Accepted 25 November 2005.

Dr. Alexandre Valotta da Silva - Lab Neurologia Experimental UNIFESP-EPM - Rua Botucatu 862 - 04023-900 São Paulo SP - Brasil. E-mail: valotta.nexp@epm.br 
observed in more than $80 \%$ of cases. Cysticercus were single in most of cases, and commonly localized in frontal and parietal lobes ${ }^{4}$. Temporal lobe epilepsy (TLE) is the most frequent epileptic syndrome and represents $60 \%$ of focal epilepsies and $40 \%$ of adult epilepsies ${ }^{5}$. Usually, TLE is divided in two subtypes: "medial TLE", in which seizures begin in medial structu res such as hippocampus, amygdala and parahippocampal gyrus, and "lateral TLE", in which seizure s begin in lateral temporal neocortex. Medial TLE is the most frequent subtype and is associated to mesial temporal sclerosis (MTS) in $65 \%$ of cases ${ }^{6,7}$. The association between NC and medial TLE has been reported by several authors ${ }^{8-10}$. Recent data show that the presence of NC does not influence the clinical and pathological profile in medial TLE patients and suggest that not all cysticercotic lesions are inevitably epileptogenic ${ }^{11-14}$. In the present report, we describe a NC case with interesting and unexpected features.

\section{CASE}

Our patient, a 50-year-old woman, with a normal development, without febrile seizures or any other initial precipitant insult (IPI), had her first seizure when she was 32years-old. Two months latter she started to present simple partial seizures weekly. The treatment with Phenitoin (300 $\mathrm{mg} / \mathrm{d}$ ) diminished the seizure frequency to once a month. During clinical follow up, brain tomography showed multiple cystic lesions in both hemispheres and CSF study was positive to neurocystiscercosis. Based in these evidences the patient was treated with anti-helm intic therapy, remaining seizure-fre after that. Four years latter the patient developed complex partial seizures (3/week) resistant to the anti-epileptic medication. Video-E EG recordings showed interictal sharp waves in both temporal regions, part i c u larly in the right hemisphere. During the recording session the patient presented two complex partial seizures with secondary generalization. Electro-clinical characteristics suggested right tem poral origin. MRI study showed typical features of mesial temporal sclerosis (MTS) in the right temporal lobe. Additionally, a cystic lesion was observed in the head of the sclerotic hippocampus (Fig 1). After presu rgical evaluation, the patient was submitted to corticoamigdalo-hippocampectomy for the treatment of pharm acoresistant TLE associated to MTS.

Resected hippocampus was fixed in $4 \%$ paraformaldehyde for $36-48$ hours at $4^{\circ} \mathrm{C}$. Five-micron paraffin sections we re processed for routine hematoxylin-eosin examination and fifty-micron vibratome sections were processed for immunocytochemistry ${ }^{15}$ against non-phosphorilated neurofilament (SMI-311, monoclonal, 1:1000, Stern berger Monoclonals Incorporated) and anti-NeuN (1:1000, Chemicon) in order to observe the cytoarchitec tural organization of the tissue. Sections were mounted in gelatin coated slides, dehydrated, covered and observed at light microscopy.

\section{RESULTS}

Neuropathological examination showed typical features of hippocampal sclerosis, i.e. neuronal loss and gliosis in CA1, CA3 and CA4, with preservation of
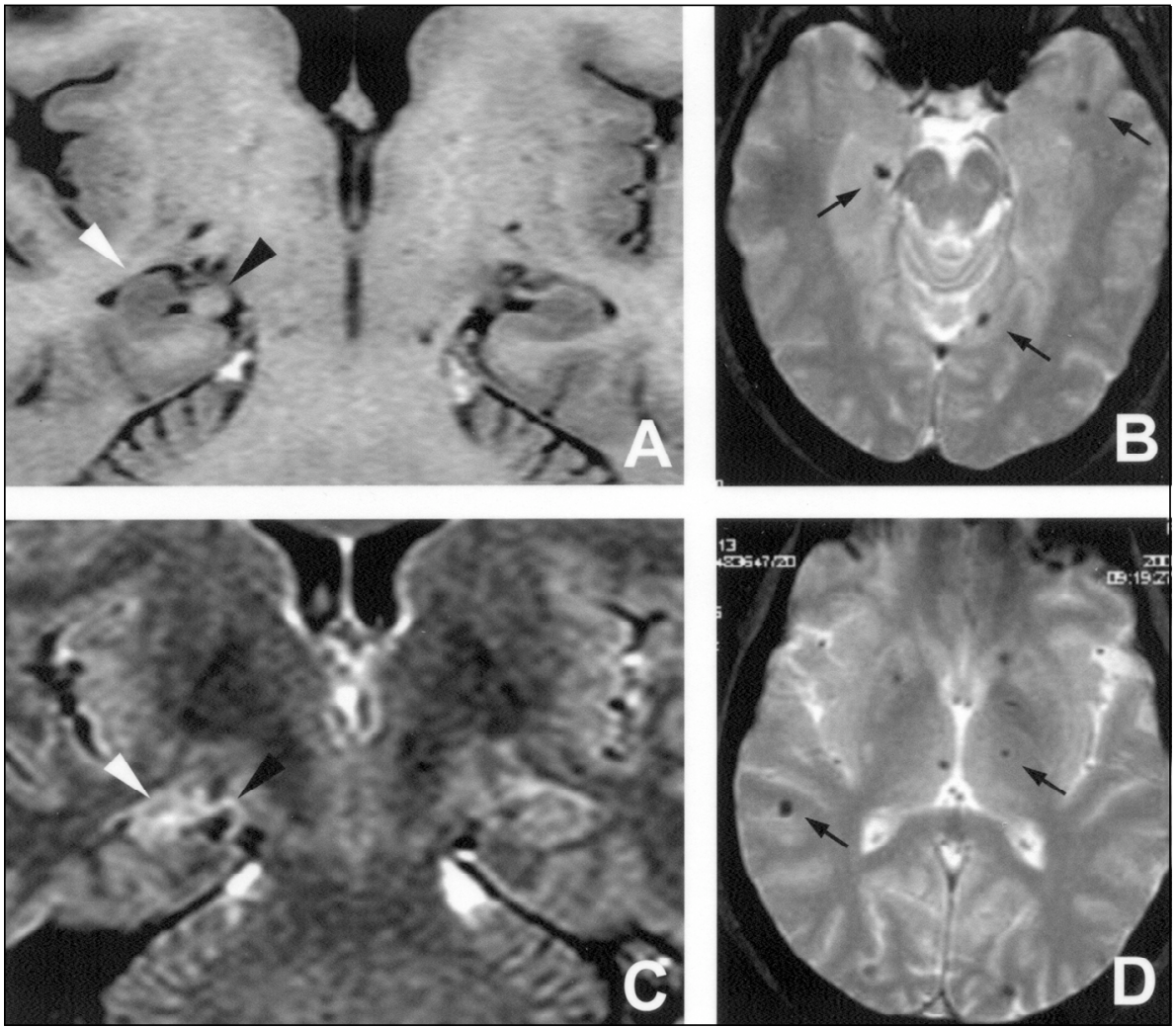

Fig 1. MRI scans performed before surgery showing hippocampal scle rosis (white arrowhead), the adja cent cystic lesion (black arrowhead), and diffuse brain calcifications (a rrows): On the left, T1-weighted inversion-recovery $(A)$ and fluidattenuated inversion-recovery (C) acquisitions in coronal plan perpen dicular to the hippocampus. On the right, T2-weighted inversion-recov ery acquisitions in axial plans $(B, D)$. 


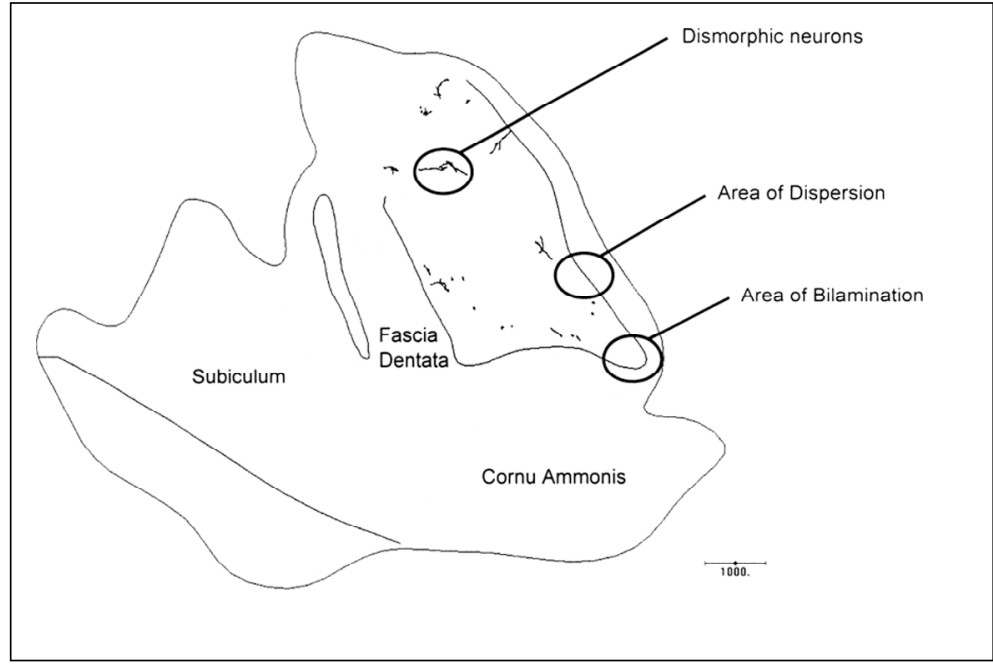

Fig 2. Camera lucida drawing.

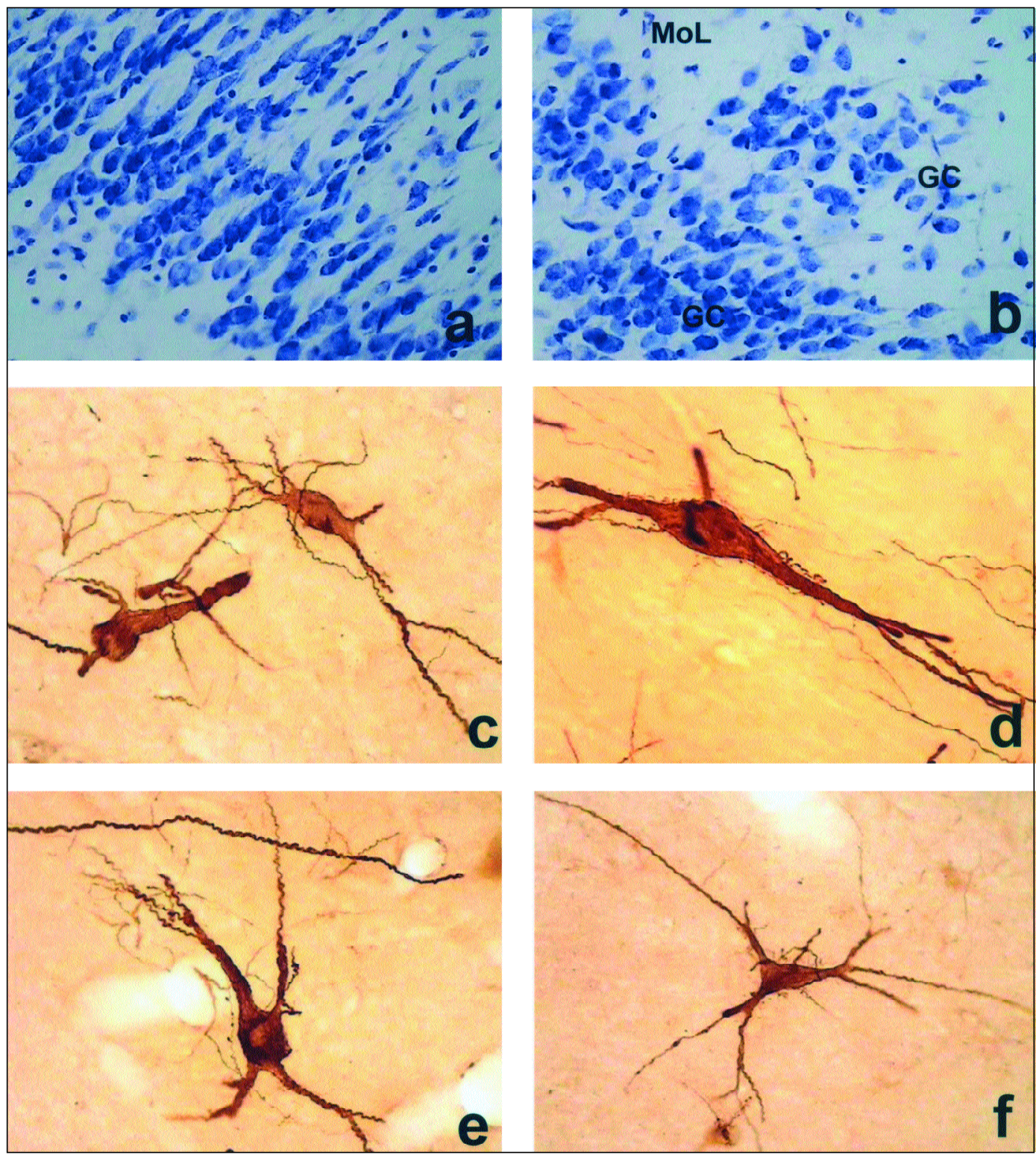

Fig 3. Histopathological findings of ressected hippocampus. (a): Granular cell dispersion; (b): Bilamination of dentade gyrus. Note the cluster of granular cells above the granular layer; $(c, d, f)$ : Dysmorphic neurons stained with SMI-311 immunocytochemistry. Optical magnification = 200X for all pictures. 
CA2 (Ammon's horn sclerosis, AHS). Additionally, and to our surprise, we observed some histological features that indicate a maldevelopmental disorder of the hippocampal formation (Figs 2, 3). Misshapen cells with abnormal orientation, size, cytoskeletal structure, and atypical dendritic processes ("dysmorphic neurons") were stained with neurofilament antibody (SMI311). Additionally, focal abnormal arrangement of dentate cells with neuronal clusters located outside the granular layer ("bilamination of dentate gyrus") was also observed. It should be noted that these findings were previously considered maldevelopmental abno malities of cortical structures ${ }^{16,17}$.

\section{DISCUSSION}

Although the hippocampal lesion may explain the development of refractory epilepsy, many questions regarding clinicopathological relationships rise from this case: Do the cyst contributed to the development of complex partial seizures? Do the cyst contributed to the hippocampal atrophy? Could the NC contribute to the development of refractory epilepsy? What could be the role of the hippocampal malformation? Since histological features observed in ressected tissue are the final picture of a complex pathological process, we can just speculate the role of each abnormality and its contribution in this case.

Frequently, seizure semiology in NC patients is related to cyst localization and its epileptogenic effect is believed to be associated with the inflammatory response. Nevertheless, calcified cysts are not invariably epileptogenic and the presence of cysticercotic lesions on MRI can be easily detected in asymptomatic individuals ${ }^{18}$. These data suggest that some additional condition could contribute to the development of NC-related seizures. In our patient, the occurrence of developmental hippocampal pathology seems to underlie the physiopathologic process.

The hippocampus is the most affected structure in refractoryTLE and, classically, shows pyramidal cell loss and gliosis in CA1, CA3 and CA4, with preservation of CA2 (Ammon's horn sclerosis, AHS). We don't know whether hippocampal sclerosis re p resents the cause or the consequence of repeated seizures in TLE patients, but some data suggest that subtle, pre-existing hippocampal malformation may contribute to the development of seizures and subsequent $A H S^{19,20}$. In our case, particular cytoarchitectural abnormalities - dysmorphic neurons and focal bilamination of the dentate gyrus - could constitute such a subtle malformation.
Dysmorphic neurons are considered the hallmark of cortical malformations ${ }^{16}$. Their morphological and $\mathrm{n}$ e u rochemical characteristics indicate a disturbance of neuronal proliferation or migration. Moreover, elect rophysiological re co rdings "in vitro" of dysplastic tissue from epileptic patients demonstrated that calcium currents and densities are greater in abnormal ("giant") compared with normal-appearing pyramidal neurons. These data support the idea that abnormal or dysplastic neurons could play a role in the generation of epileptic activity in our patient ${ }^{21}$.

The dentate gyrus alterations in TLE have been la rgely debated ${ }^{22,23}$. Some authors consider the bilamination of the dentate gyrus a variant of cellular dispersion, although this abnormality (double granule cell layer) could be related to a disturbance in granule cell migration during development ${ }^{24,25}$. In this study, we chose to differentiate the terms "dispersion" and "bilamination" due to the clear morphological diffe rences and distinct mechanisms possibly responsible for these alterations. Moreover, preliminary data from our laboratory show that specific morphometric parameters can easily identify the different natures of dispersed and bilaminated regions (unpublished data).

Based on clinical history and histopathological findings, we may suggest the following pathophysiological explanation for this particular case: (1) some p re-natal abnormality induced a maldevelopmental disorder of the hippocampal formation; (2) the malfo rmation lowered the threshold for NC-induced seizures; (3) chronic seizures contributed to additional hippocampal damage; and (4) the patient evolved to refractoryepilepsy associated with hippocampal sclerosis.

\section{REFERENCES}

1. Centers for Diseases Control. Recommendations of the International task Force for Disease Eradication (ITFDE), Mortality and Morbidity Weekly Report 1993;42:1-25.

2. Medina MT, Rosas E, Rubio-Donnadieu F, Sotelo J. Neurocysticercosis as the main cause of late-onset epilepsy in Mexico. Arch Intern Med 1990;150:325-327

3. Pal DK, Carpio A, Sander JW. Neurocysticercosis and epilepsy in developing countries. J Neurol Neurosurg Psychiatry 2000;68:137-143.

4. Agapejev S. Epidemiology of neurocysticercosis in Brazil. Rev Inst Med Trop S Paulo 1996;38:207-216.

5. Pedley TA. Neurobiologia da epilepsia do lobo temporal. In Guerreiro CA, Guerreiro MM (eds). Epilepsia. São Paulo, Lemos Editorial, 1996:1929.

6. Babb TL, Brown WJ. Pathological findings in epilepsy. In Engel J Jr (ed) Surgical treatment of epilepsies. New York: Raven Press, 1987: 511-540.

7. Wieser HG, Engel J Jr, Williamsom PD, et al. Surgically remedial temporal lobe syndromes. In: Engel J JR, ed. Surgical treatment of the epilepsies. New York: Raven Press, 1993:49-63

8. Chung CK, Lee SK, Chi JG.Temporal lobe epilepsy caused by intrahippocampal calcified cysticercus: a case report.J Korean Med Sci 1998; 13:445-448. 
9. Garg RK, Karak B, Mohan Kar A. Neuroimaging abnormalities in Indian patients with uncontrolled partial seizures. Seizure 1998;7:497-500.

10. Leite JP, Terra-Bustamante VC, Fernandes RM, et al. Calcified neurocysticercotic lesions and postsurgery seizure control in temporal lobe epilepsy. Neurology 2000;55:1485-1491

11. Trelles JO, lazarte J. Cistiscercosis cerebral: estudo clínico, histopatológico y parasitológico. Rev Neuropsiquiatr (Lima) 1940;3:857-894.

12. Morales NMO, Agapejev S, Morales RR, Padula NAMR, Lima MMF. Clinical aspects of neurocysticercosis in children. Pediatr Neurol 2000;22:287-291.

13. Andrade FAS. Neurocis tice rcose aspectos clínicos, epidemiológicos e diagnósticos: estudo prospectivo de 157 pacientes na Região Nordeste, Bahia. Tese. Niterói, 1997.

14. Agapejev S. Aspectos clínico-epidemiológicos da neurocistice rooseno Brasil. Arq Neuropsiquiatr 2003;61:822-828.

15. Silva AV, Sanabria ERG, Cavalheiro EA, Spreafico R. Alterations of the neocortical GABAergic system in the pilocarpine model of temporal lobe epilepsy: neuronal damage and immunocytochemical changes in chronic epileptic rats. Brain Res Bull 2002;58:417-421.

16. Sp reafico R, Avanzini G, Andermann F. Abnormal cortical development and epilepsy. London: John Libbey \& Company, 1999.

17. Blümcke I, Thom M, Wiestler OD. Ammon's horn sclerosis: a maldevelopmental disorder associated with temporal lobe epilepsy. Brain Pathol 2002;12:199-211.
18. Carpio A, Escobar A, Hauser WA. Cysticercosis and epilepsy: a critical review. Epilepsia 1998;39:1025-1040.

19. Fernandez G, Effenberger O, Vinz B, et al. Hippocampal malformation as a cause of familial febrile convulsions and subsequent hippocampal sclerosis. Neurology 1998;50(4):909-917.

20. Sloviter RS, Pedley TA. Subtle hippocampal malformation: importance in febrile seizures and development of epilepsy. Neurology 1998;50: 846-849.

21. Cepeda C, Hurst RS, Flores-Hernandez J, Hernandez-Echeagaray E, et al. Morphological and electrophysiological characterization of abnormal cell types in pediatric cortical dysplasia. J Neurosci Res 2003;72: 472-486.

22. Houser CR. Granule cell dispersion in the dentate gyrus of humans with temporal lobe epilepsy. Brain Res 1990;535:195-204.

23. Lurton D, El Bahh B, Sundstrom L, Rougier A. Granule cell dispersion is correlated with early epileptic events in human temporal lobe epilepsy. J Neurol Sci 1998;154:133-136.

24. Rougier A, Brana C, Arthaud S, Le Gal La Salle G. Épilepsie temporale et dédoublement complet de la couche des cellules granulaires du gyrus denté. Rev Neurol (Paris) 2003;159:568-570.

25. Blümcke I, Thom M, Wiestler OD. Ammon's horn sclerosis: a maldevelopmental disorder associated with temporal lobe epilepsy. Brain Pathol 2002;12:199-211. 